\title{
Chitosan Composite of Crab Shell and Hydroxyapatite of Tuna Fish Bone as Biomaterials for Guided Tissue Regeneration
}

\section{Komposit Kitosan dari Cangkang Kepiting dan Hidroksiapatit dari Tulang Ikan Tuna sebagai Biomaterial untuk Memandu Regenerasi Jaringan}

\author{
Thamrin Wikanta ${ }^{1}$, Erizal $^{2}$, and Sugiyono ${ }^{1}$ \\ ${ }^{1}$ Research and Development Center for Marine and Fisheries Product Processing and Biotechnology, \\ JI. K.S. Tubun Petamburan VI, Jakarta Pusat 10260, Indonesia \\ ${ }^{2}$ Pusat Aplikasi Tenaga Nuklir, Badan Tenaga Atom Nasional (PATIR-BATAN), JI. Lebak Bulus Raya 49, Jakarta Selatan. \\ *Correspondence Author: thamrinwikanta@yahoo.com \\ Article history: \\ Received: 5 Januari 2013; Revised: 24 September 2013; Accepted: 25 September 2013
}

\begin{abstract}
The needs of membrane biomaterials to prevent the migration process of epithelial cells into the bony area after tooth withdrawal process, for filler the holed tooth and to cure gingivitis have increased significantly. In this study, a biomembranes composed of chitosan (CTS) and hydroxyapatite (HA) were prepared. CTS was made of crab shell and HA was made of tuna fish bone. There were 4 groups of treatments, i.e.: $\mathrm{KO}$ : only $4 \mathrm{~g}$ CTS as a control; $\mathrm{K} 1$ : combination of 4 $\mathrm{g}$ CTS and $2 \mathrm{~g} \mathrm{HA}$; K2: combination of $4 \mathrm{~g}$ CTS and $4 \mathrm{~g} \mathrm{HA}$; and K3: combination of $4 \mathrm{~g}$ CTS and 6 $\mathrm{g} \mathrm{HA}$. The dried and solid membrane was soaked in $5 \% \mathrm{Na}_{2} \mathrm{SO}_{3}$ for 1 hour, and then dried in oven at $60{ }^{\circ} \mathrm{C}$ for 24 hours. The composite membrane properties, i.e.: water absorption, biodegradation, tensile strength, elongation at break, functional group (by FTIR), and microstructure (by SEM) were evaluated. Result showed that the increasing of HA content in membrane will decreasing the water absorption. The increasing of HA content in membrane and soaking time in Phosphate Buffered Saline (PBS), can increase in biodegradation rate. The biodegradation rate of membrane was about $4.44-6.01 \%$ during 27 days of soaking time. The increasing soaking time in PBS can decrease the tensile strength of membrane at about $18.33 \%-21.17 \%$ and decreased the elongation at break at about $26.64 \%-59.94 \%$. FT-IR analysis indicated that there was a crosslinking between a CTS-HA composite membrane and $\mathrm{Na}_{2} \mathrm{SO}_{3}$. Among all the composites studied, CTS-HA (4/2 g/ g) composite membrane is the best one for Guided Tissue Regeneration (GTR).
\end{abstract}

Keywords: biomembrane, chitosan, hydroxyapatite, tensile strength, elongation at break

\section{ABSTRAK}

Kebutuhan terhadap biomaterial membran untuk mencegah proses epitelialisasi sel yang bermigrasi ke daerah tulang setelah proses pencabutan gigi, untuk mengisi gigi berlubang, dan radang gusi telah meningkat pesat. Pada percobaan ini dibuat biomembran dari campuran chitosan (CTS) dengan hidroksiapatit (HA). CTS dibuat dari cangkang kepiting dan HA dibuat dari tulang ikan Tuna. Dipersiapkan 4 kelompok perlakuan, yaitu: K0: hanya $4 \mathrm{~g}$ CTS sebagai kontrol; K1: campuran dari $4 \mathrm{~g}$ CTS dan $2 \mathrm{~g} \mathrm{HA}$; K2: campuran dari $4 \mathrm{~g}$ CTS dan $4 \mathrm{~g} \mathrm{HA}$; dan K3: campuran dari $4 \mathrm{~g}$ CTS dan $6 \mathrm{~g} \mathrm{HA}$. Membran kering dan padat direndam dalam larutan $\mathrm{Na}_{2} \mathrm{SO}_{3} 5 \%$ selama 1 jam, dan kemudian dikeringkan dalam oven pada $60{ }^{\circ} \mathrm{C}$ selama 24 jam. Sifat membran campuran dievaluasi tentang daya serap air, biodegradasi, kekuatan tarik, perpanjangan putus, gugus fungsional (dengan FTIR), dan struktrur mikronya (dengan SEM). Hasil menunjukkan bahwa meningkatnya kandungan HA dalam membrane mengakibatkan menurunnya absorpsi air. Meningkatnya kandungan HA dalam membrane dan meningkatnya waktu perendaman dalam PBS mengakibatkan meningkatnya laju biodegradasi. Laju biodegradasi membran sekitar 4.44$6.01 \%$ selama 27 hari perendaman. Meningkatnya waktu perendaman dalam PBS mengakibatkan menurunnya kekuatan tarik membran sekitar $18.33 \%-21.17 \%$ dan menurunnya perpanjangan putus sekitar $26.64 \%-59.94 \%$. Analisis FT-IR mengindikasikan terdapat ikatan silang antara membrane komposit CTS-HA dan $\mathrm{Na}_{2} \mathrm{SO}_{3}$. Diantara semua komposit yang dipelajari, komposit CTS-HA (4/2 g/g) adalah yang terbaik untuk Memandu Regenerasi Jaringan (MRJ).

Kata Kunci: biomembran, kitosan, hidroksiapatit, kekuatan tarik, perpanjangan putus

Permalink/DOI: http://dx.doi.org/10.15578/squalen.v8i3.85 


\section{Introduction}

Guided Bone Regeneration (GBR) is a technique or procedure to treat a bone defect by placing a membrane as a tissue barrier to allow a selective bone tissue growing or to regenerate in a localized space. GBR or commonly called as Guided Tissue Regeneration (GTR) as an attempt to regenerate bone, has been practiced in dental care to provide the opportunity for new tooth formation or repairing a defect tooth. Soft tissue grows very fast, while bone grows more slowly (Anon., 2006; Tal et al., 2012). The membrane serves as a physical or mechanical barrier to create a space around the defect tooth or removed tooth, to allow bone to regeneration, and to prevent the epithelial cells migration into the bony area (Chen et al., 2004; Kuo et al., 2009).

Recently, the need of biomaterial has increased significantly, i.e. as a membrane to overcome the epithelial cells migration into the bony area after tooth withdrawal process, to fill the holed tooth, and to cover gingivitis. Any other applications of biomaterial are on orthopedic, cardiovascular, wound healing surgical appliances (Anon., 2011; Tal et al., 2012; Anon, 2013a; Anon., 2013b). There are many kinds of GTR or GBR membrane materials used in experimental and clinical studies. Some of those materials are made of polytetrafluoroethylene (PTFE) and collagen. Both materials have disadvantageous. Hence, many efforts have been done to produce similar GTR or GBR membrane that relatively inexpensive, safe, non-toxic, non-antigenic, and non-inflammatory properties on bone tissue.

Chitosan (CTS) and its derivatives used as bone saffald materials are biocompatible, biodegradable, biosorption, osteoinduction, osteoconduction, and accelerate wound healing properties when apply as a bone scaffold material. It exhibit low degradation rate and has excellent gel-forming property (Chen et al., 2004; Kuo et al., 2009, 2009a; Peniche et al., 2010; Wawro et al., 2011).

Hydroxyapatite $(\mathrm{HA}), \mathrm{Ca}_{10}\left(\mathrm{PO}_{4}\right)_{6}(\mathrm{OH})_{2}$, a major inorganic component of bone and teeth, has been extensively applied for biomedical implant and bone or tissue regeneration barrier membrane due to its bioactive, biocompatible, biodegradable, and osteoconductive properties (Chen et al., 2002; Peniche et al., 2010; Ramli et al., 2011; Ai et al., 2011). To date, fish products waste, such as tuna bone, was utilized as an additive or filler of fish feed, i.e. as a source of calcium. To increase its value- added, the waste is used as a biomaterial source i.e GTR, with assumption this calcium source is cheaper and safer compare to the synthetic one.

Research to produce the membrane composed of CTS and HA has been done. The properties of membrane formed were evaluated, i.e. water absorption capacity, tensile strength and elongation at break, and biodegradation properties. In order to obtain better end product, the treatment which has the best properties was impregnated by crosslinking to the $\mathrm{Na}_{2} \mathrm{SO}_{3}$.

\section{Material and Methods}

\subsection{Material}

Materials used in this research were chitosan and hydroxyapatite. Chitosan was produced by PT Biotech Surindo, Cirebon, and hydroxyapatite was produced from Tuna (Thunnus sp) fish bone in the lab. Tuna bone was obtained from Muara Angke, Jakarta. Identification of membrane microstructure was using Scanning Electron Microscope (SEM) at BATAN, Serpong.

\subsection{Method}

Production of HA powder. Tuna bone was boiled at $80{ }^{\circ} \mathrm{C}$ for 30 minutes, then washed and heated in autoclave $\left(121^{\circ} \mathrm{C}, 1 \mathrm{~atm}, 20\right.$ minutes). The bone was stand to cool, cut into small pieces $(5-10 \mathrm{~cm})$, then reboiled at $100^{\circ} \mathrm{C}$ for 30 minutes. To eliminate protein, bone was extracted by $\mathrm{NaOH} 1,5 \mathrm{~N}$ at $60^{\circ} \mathrm{C}$ for 2 hours. Then the bone was stand to cool, neutralized by washing with distilled water, and dried in oven at 60 ${ }^{\circ} \mathrm{C}$ for 24 hours. Finally the HA powder from tuna bone was sieved at 300 mesh of pore size $( \pm 50 \mu \mathrm{m})$.

Production of CTS-HA composite membrane. Four groups of CTS-HA mix treatment were prepared triplicate with the composition of: $\mathrm{KO}$, (CTS-HA=4/0 $\mathrm{g} / \mathrm{g}$ ); K1, (CTS-HA=4/2 g/g); K2, (CTS-HA=4/4 g/g); $\mathrm{K} 3$, (CTS-HA=4/6 g/g). CTS $(48 \mathrm{~g})$ was dissolved in of $2 \%$ acetic acid solution $(900 \mathrm{ml})$ then it was divided into 12 beaker glasses, each containing $75 \mathrm{ml}$ of the solution, each contain $4 \mathrm{~g}$ CTS dilluted in $25 \mathrm{ml}$.

$\mathrm{KO}$, control, is a CTS solution, $2 \mathrm{~g}$ CTS diluted in $25 \mathrm{ml}$ distilled water. $\mathrm{K} 1, \mathrm{~K} 2$, and $\mathrm{K} 3$ is CTS solution with the addition of $2 \mathrm{~g}, 4 \mathrm{~g}$, and $6 \mathrm{~g}$ of HA respectively.

Each of CTS-HA mix solution was poured into $10 \times 10 \times 0.3 \mathrm{~cm}^{3}$ plastic mold. Then it was dried at room temperature. The dried and solid membrane product was soaked in $\mathrm{Na}_{2} \mathrm{SO}_{3} 5 \%$ solution, and then was dried in oven at $60{ }^{\circ} \mathrm{C}$. The prepared CTS-HA composite membranes were stored in desiccator for further analysis.

Characterization of CTS-HA composite membrane. Physical and chemical properties (water absorption, biodegradation, tensile strength, elongation at break, functional group) of the CTS-HA 
composite membrane was characterized by FTIR, and microstructure by SEM (Chen et al., 2004; Kuo et al., 2009a).

Water absorption test. Membrane was cut into small pieces with size of $2 \times 2 \times 0.5 \mathrm{~cm}^{3}$. Membrane was dried in oven at $60{ }^{\circ} \mathrm{C}$ for 1 hour until constant weight $\left(\mathrm{W}_{0}\right)$ reacted and soaked in Phosphate Buffered Saline (PBS) pH 7.4 consecutively for 1, 3, 5, 7, 9, 11, 13 \&15 minutes. Membrane was taken out from the solution and the water on the membrane surface was blotted with tissue paper, then weight (Wn). The water absorbed by membrane was calculated with the equation as follow (Chen et al., 2004; Yuan et al., 2008; Kuo et al., 2009a):

$$
\text { Water absorption }(\%)=\left(\mathrm{Wn}-\mathrm{W}_{0}\right) / \mathrm{W}_{0} \times 100
$$

Note:

$\mathrm{Wn}=$ weight $(\mathrm{mg})$ of wet membrane after swelling at day-n

$\mathrm{W}_{0}=$ weight $(\mathrm{mg})$ of dry membrane at initial time

Biodegradation test. Membrane was cut into small pieces with size of $2 \times 2 \times 0.5 \mathrm{~cm}^{3}$. Membrane was dried in oven at $60{ }^{\circ} \mathrm{C}$ for 1 hour until constant weight $\left(\mathrm{W}_{0}\right)$ reached then it was soaked in $\mathrm{PBS} \mathrm{pH}$ 7.4 for 27 days. At interval of 3 days soaking time, the biodegradation was measured and calculated as follow (Chen et al., 2004; Kuo et al., 2009a):

$$
\text { Biodegradation }(\%)=\left(\mathrm{Wn} /\left(\mathrm{W}_{0}\right) \times 100\right.
$$

Note:

$$
\begin{aligned}
\begin{array}{l}
\mathrm{Wn}= \\
\text { weight }(\mathrm{mg}) \text { of dry membrane after } \\
\text { degradation at day- } \mathrm{n}
\end{array} \\
\mathrm{W}_{0}=\text { weight }(\mathrm{mg}) \text { of dry membrane at initial time }
\end{aligned}
$$

\section{Test of tensile strength and elongation at break.}

Membrane was cut using a Dumbble shape No.3 JISK63011971 (Toyoseiki) in Dumbble (Aoki, 1991). The membrane was clamped at both side using tensiometer Strograph-RI (Toyoseiki), which attributed with a special ruler. Attraction on membrane was conducted until the membrane was broken. The attraction power when the membrane broken is stated as a tensile strength, and the addition length of membrane when the membrane broken is stated as an elongation at break (Kuo et al., 2009a). The value of tensile strength and elongation at break were calculated with the equation as follow:
Tensile strength $\left(\mathrm{S}, \mathrm{kg} / \mathrm{cm}^{2}\right)=\mathrm{F} / \mathrm{A}$

Elongation at break $(E, \%)=($ Ln-Lo $) /$ Lo $\times 100$ Note:

$$
\begin{aligned}
& \begin{array}{r}
F= \\
\text { the power shown when the membrane was } \\
\text { broken }(\mathrm{kg})
\end{array} \\
& \begin{aligned}
& \mathrm{A}= \text { thick } \mathrm{x} \text { widh }=\text { the initial surface area of membrane } \\
&\left(\mathrm{cm}^{2}\right)
\end{aligned} \\
& \mathrm{E}=\text { elongation at break }(\%) \\
& \mathrm{Lo}=\text { the initial length }(\mathrm{mm}) \text { between two marker line } \\
& \mathrm{Ln}=\text { the final length }(\mathrm{mm}) \text { between two marker line } \\
& \text { when the membran broken }
\end{aligned}
$$

Data analysis. Data was analyzed descriptively to know the weight variation of the membrane properties of the synthesized product.

\section{Result and Discussion}

\subsection{Water absorption}

Water absorption is one of the important parameters of CTS-HA membrane. When membrane apply on the tooth space from which the tooth has been withdrawn, the membrane must swell as soon as possible to make it easy to combine with epithelial cells. If the membrane does not swell quickly, the membrane still dry, and it will difficult to be tailored. In application, membrane used must be able to absorb water in 15 minutes.

The relationship between the soaking time and the water absorption of CTS-HA membrane at various composition of membrane is presented in Figure 1. It is shows that at 1 minute soaking time, the membrane can absorb water, i.e. : for CTS-HA (4/0 $\mathrm{g} / \mathrm{g}$ ) membrane at about $51.85 \%$, for CTS-HA (4/2 g/ g) membrane at about $84.50 \%$, for CTS-HA (4/4 g/g) membrane at about $63.62 \%$, and for CTS-HA (4/6 g/ g) membrane at about $51.13 \%$. The higher the $\mathrm{HA}$ content in the CTS-HA membrane, the lower the capacity of membrane to absorb water. Almost all CTS-HA membranes observed were able to reach the equilibrium condition in 5 minutes. The quicker the membrane, swelled the better its properties for clinical and surgical procedure as stated by Kuo et al. (2009). Increasing of the soaking time from 1 to 15 minutes, cause slowly increase of the amount of water absorbed by CTS-HA membrane. It reach the constant value of equilibrium condition at various time in 5 minutes.

In 15 minutes, water absorbed by $\mathrm{K} 0, \mathrm{~K} 1, \mathrm{~K} 2$, and $\mathrm{K} 3$ was $131.78 \%, 98.97 \%, 90.81 \%$, and $56.41 \%$ respectively. 


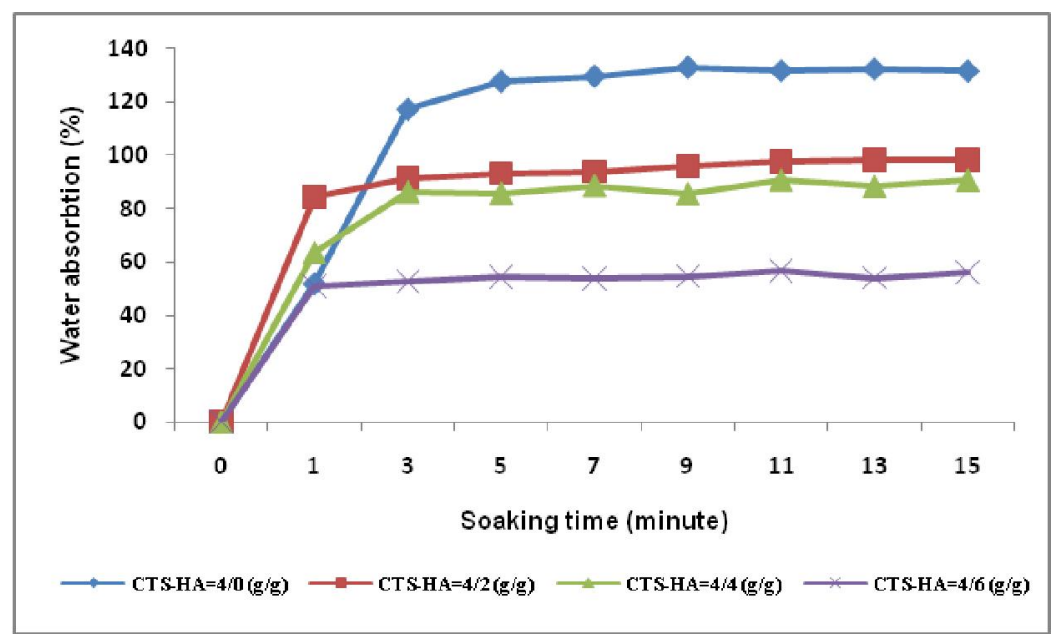

Figure 1. The relationship between the soaking time (minute) and the water absorption (\%) of CTS-HA membrane at various composition of membrane.

It shows that the increasing of HA content in CTSHA membrane leads to decrease the water absorption capacity of membrane. Although the KO has the highest water absorption capacity, it is not a composite membrane and it will easy to disintegrate whenever it has absorbed a lot of water. Among three composite membrane treatments, the CTS-HA (4/2 $\mathrm{g} / \mathrm{g}$ ) membrane has the highest water absorbtion value.

Among three composite membrane treatments, of experiment, the $\mathrm{K} 1$ membrane was the best one because it has the highest water absorption value. Yuan et al. (2008) mentioned that water uptake by membrane is affected by many factors including: 3-D pore structure, porosity, mechanical strength, and hydrophilicity.

In this case, the hidrophilicity of HA is the factor mostly affected the water uptake by composite CTSHA membrane. HA is an inorganic substance that is insoluble in water. Hence, increasing the HA content in CTS-HA membrane, will decrease the water absorbed by membrane or diffused into the membrane pores. CTS is a hydrophilic organic substance that contains an - $\mathrm{NH}$ and -OH functional group, and able to absorb a lot of water. Increasing the soaking time of CTS-HA. Increase the amout of water absorbed by the CTS-HA membrane until it is reached the maximum point, at the equilibrium condition, where the membrane was not able to absorb more water. Kuo et al. (2009a) prepared a CTS/ $\alpha-T C P$ (tricalciumphosphate) composite membrane with the ratio of $35 / 65 \% ; 67 / 33 \%$; and $90 / 10 \%(\mathrm{w} / \mathrm{v})$ and reported that the higher TCP content in membrane the lower water content of membrane from $48.5 \%$; $48.4 \%$ and $33.2 \%$.

\subsection{Membrane biodegradation}

Hopefully, in practical application, membrane will able to be degraded in accordance with the more tooth spaces or pores covered by additive material. The effect of soaking membrane time in the PBS for 27 days, Figure 2.

It shows that the increasing soaking time, increasing the membrane weight loss. In 27 days time of soaking, the membrane weight loss was in the range of $3.15-6.61 \%$, according to $\mathrm{K} 3>\mathrm{K} 2>\mathrm{K} 1>\mathrm{K} 0$. The biodegradation of CTS-HA membrane increased with increasing of the HA content. Among three composite membrane treatments of experiment, the $\mathrm{K} 1$ membrane was the best one because it has the lowest weight loss value. Although the $\mathrm{KO}$ has the low weight loss value, it is not a composite membrane that will easy to disintegrate or to dissolve in more acidic environment condition or under mechanical pressure.

As an effective barries, the membrane should have a good mechanical strength, safe, nontoxic, nonantigenic, no inflammatory responses, it also should can be maintained for along time for tissue guidance to take effect, to prevent the in-growth of cells from some undesirable tissues (Kuo et al., 2009, 2009a; Teng et al., 2008; Zo et al., 2012). Based on its properties the CTS-HA membrane components, i.e. both CTS and HA are have good properties. CTS as a bone scaffold material has biocompatibility, biodegradation, antibacterial, osteoinduction and osteoconduction. HA from natural sources, i.e. fish bone, has biocompatibility, bioactivity, nontoxicity, good mechanical strength, and same chemical composition same with bone. In this research, low biodegradation of CTS-HA membrane means suitable 


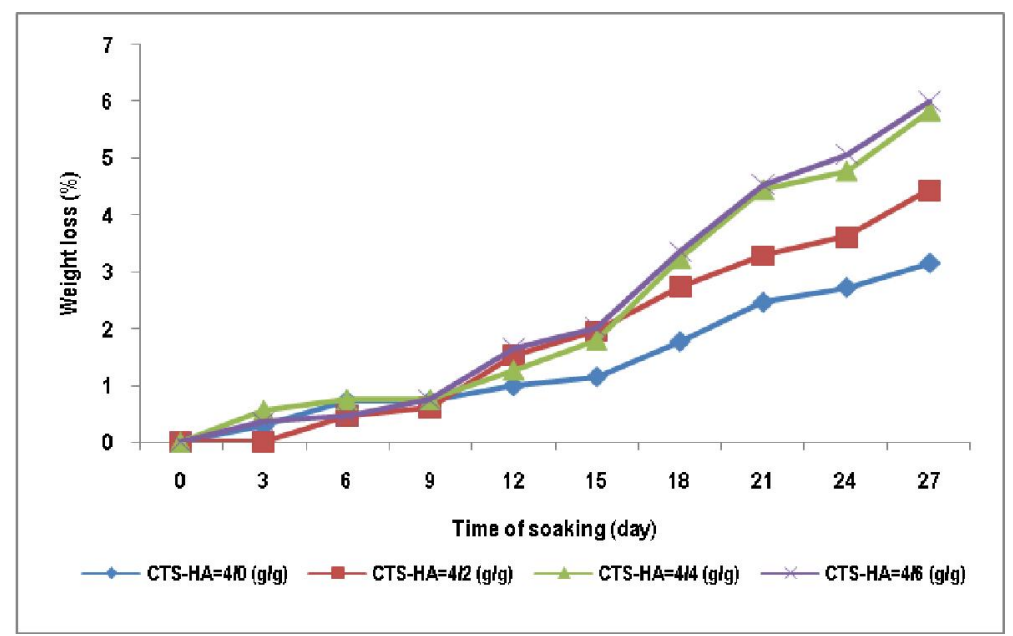

Figure 2. The relationship between time of soaking (day) in PBS and the weight loss (\%) of CTS-HA membrane at various composition of membrane.

as a membrane for GTR and it can be used for long time for tissue guidance. Kuo et al. (2009a) stated that in practical application, membranes for GTR generally needed 4-6 weeks to secure the successful restoration of periodontal tissues

According to Kuo et al. (2009), the biodegradation rate of CTS-HA membrane were in the range of 5$10 \%$, which is suitable or meet the requirement for GTR application in periodontal. Freitas et al. (2011) found that using High Molecular Weight CTS (HMWC) and Low Molecular Weight CTS membranes (LMWC) on wound of in vivo application for 7 days present a variable degree of inflammation as a respons to the initial resorption process. Afterwards, within 15 days or more, when the resorption has been totally reached, the tissue has apparently organized without inflamation or the tissue in a healthy condition. It means that CTS membrane is applicable for GTR.

\subsection{Effect of soaking time on the tensile strength}

Tensile strength of membrane is one of the important mechanical properties for GTR application. Generally, membrane used in the teeth area is easy to fall out, especially when it is used to bite or chew something. Membrane must have good properties, such as elastic, flexible, and high strength, keep stand against attraction or pressure and able to follow the tooth moving.

The effect of soaking time on the tensile strength of CTS-HA membrane at various composition of membrane is presented in Figure 3. It shows that the increasing of the HA content in CTS-HA membrane, caused decrease of the tensile strength value; and the increasing of the soaking time until 4 weeks, caused decrease of the tensile strength of membrane, at various composition of membrane.

Reduction the tensile strength of membrane after soaking in PBS until week-4 comparing to the initially tensile strength, present in Table 1. It shows that the increasing of the HA content in CTS-HA membrane, lead to an increase in the reduction of tensile strength until $21.17 \%$. It means that after soaking in PBS until week-4 membrane was more britle. Consequently, when the membrane, no more availed it will be easier to take it out from tooth space, and not necessarily a surgical operation. Among three CTS-HA composite membrane treatments $(4 / 2 \mathrm{~g} / \mathrm{g}$, $4 / 4 \mathrm{~g} / \mathrm{g}$, and $4 / 6 \mathrm{~g} / \mathrm{g}$ ) of experiment, the CTS-HA (4/2 $\mathrm{g} / \mathrm{g}$ ) was the best one because it has the highest tensile strength value. The tensile strength reduction of CTS-HA (4/2 g/g) composite membrane and the CTS-HA (4/0) non-composite membrane, are relatively similar.

\subsection{Effect of soaking time on the elongation at break}

The effect of soaking time in PBS on the elongation at break of CTS-HA membrane at various composition of $\mathrm{HA}$ is presented in Figure 4. It shows that the elongation at break value of all treatments of CTS-HA membrane decreased along with the increasing of soaking time until week-4. At week-4, the elongation at break value for the CTS-HA (4/0 g/g) membrane was $86.66 \%$ from initially $130 \%$, for the CTS-HA (4/2 $\mathrm{g} / \mathrm{g}, 4 / 4 \mathrm{~g} / \mathrm{g}$, and $4 / 6 \mathrm{~g} / \mathrm{g}$ ) were $56.66 \%, 50.00 \%$, and $46.66 \%$ from initially $126.00 \%, 76.66 \%$, and $73.30 \%$, respectively.

Among three composite membrane treatments CTS-HA ( $4 / 2 \mathrm{~g} / \mathrm{g}, 4 / 4 \mathrm{~g} / \mathrm{g}$, and $4 / 6 \mathrm{~g} / \mathrm{g})$ of experiment, 
Table 1. Reduction of tensile strength after membrane was soaking in PBS until week-4.

\begin{tabular}{ccc}
\hline Membrane composition & Tensile strength reduction (\%) & Remarks \\
\hline CTS-HA $(4 / 0 \mathrm{~g} / \mathrm{g})$ & 18.33 & Based component membrane \\
CTS-HA $(4 / 2 \mathrm{~g} / \mathrm{g})$ & 18.34 & Composite membrane \\
CTS-HA $(4 / 4 \mathrm{~g} / \mathrm{g})$ & 20,8 & Composite membrane \\
CTS-HA $(4 / 6 \mathrm{~g} / \mathrm{g})$ & 21,17 & Composite membrane \\
\hline
\end{tabular}

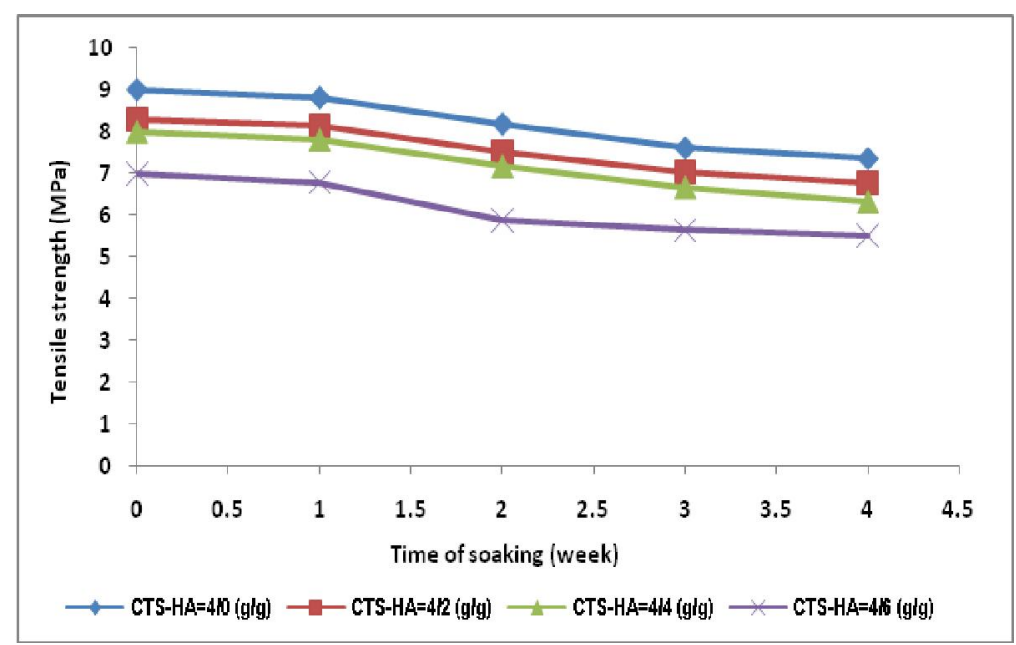

Figure 3. The relationship between time of soaking (week) in PBS and the tensile strength (MPa) of CTS-HA membrane at various composition of membrane.

the CTS-HA $(4 / 2 \mathrm{~g} / \mathrm{g})$ membrane was the best one because it has the highest elongation at break value, either at the initiall or final experiment time. The percentage of reduction value of the elongation at break for all the CTS-HA membranes after soaking in PBS until week-4 and comparing to the initial elongation at break value is presented in Table 2. The CTS-HA (4/2 g/g) composite membrane has the highest reduction of elongation at break, i.e $55.25 \%$. However, among three composite membrane treatments, this composite membrane has the highest elongation at break value, either at the initiall or finall experiment time. It means that membrane after soaking in PBS until week-4 becomes more britle. Hence, in practical application, when the used of membrane has finished, it will be easier to take membrane out from tooth space, and no necessarily any surgical operation.

\subsection{Characterization of CTS-HA membrane}

\section{Fourier Transform Infra Red (FTIR)}

The FTIR spectrum of HA is characterized by functional group of $\mathrm{O}-\mathrm{H}, \mathrm{P}-\mathrm{O} / \mathrm{P}=\mathrm{O}$ at the wave lenght of $3205.69-3560.59 \mathrm{~cm}^{-1}$ and $1030.20 \mathrm{~cm}^{-1}$ as shown in Table 3. The wave lenght of specific functional group of the sample, i.e O-H and $\mathrm{P}-\mathrm{O} / \mathrm{P}=\mathrm{O}$ were in the range of wave lenght as stated by Silverstein et al. (2000). Chen et al. (2002) obtained the wave number of specific functional group of their HA sample were slightly higher from which we obtained, but it still in the range that stated by Silverstein et al. (2000). It means that the HA obtained was in high purity.

In order to obtain better properties of the end product, the treatments (the best composite and based component membranes) were impregnated by crosslinking with $\mathrm{Na}_{2} \mathrm{SO}_{3}$, then it were evaluated by FTIR. The FTIR spectrum of CTS or CTS-HA $(4 / 0 \mathrm{~g} /$ g) membrane before and after soaking in $\mathrm{Na}_{2} \mathrm{SO}_{3}$ solution were characterized by the wave lenght of certain functional group, that are $\mathrm{NH} ; \mathrm{CH}$ stretching; $\mathrm{C}=\mathrm{O}$; and $\mathrm{C}-\mathrm{O}-\mathrm{C}$. Result of FTIR spectrum identification of CTS-HA $(4 / 0 \mathrm{~g} / \mathrm{g})$ membrane before and after soaking in $\mathrm{Na}_{2} \mathrm{SO}_{3}$ solution is presented in Table 4.

Comparing the FTIR spectrum of CTS or CTS-HA $(4 / 0 \mathrm{~g} / \mathrm{g})$ membrane before and after soaking in $\mathrm{Na}_{2} \mathrm{SO}_{3}$ solution revealed that the peak width of $\mathrm{NH}$ group at the wave lenght of $3300 \mathrm{~cm}^{-1}$ shortened after its membrane soaked in $\mathrm{Na}_{2} \mathrm{SO}_{3}$ solution. It means that there is an ionic bond between $\mathrm{CTS}$ and $\mathrm{SO}^{-2}$ which 


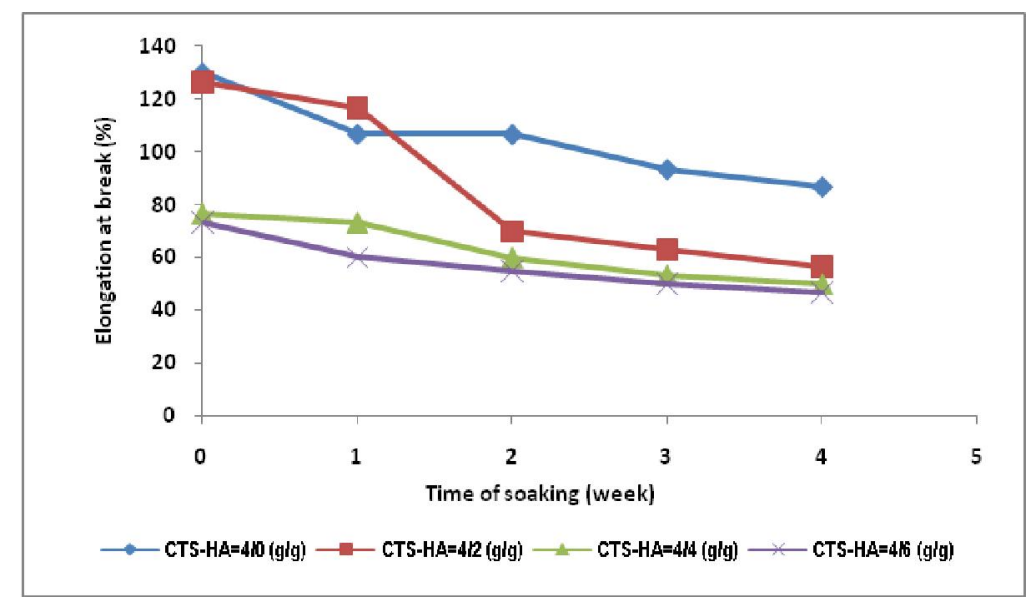

Figure 4. The relationship between time of soaking (week) in PBS and the elongation at break (\%) of CTS-HA membrane at various composition of membrane.

Table 2. Reduction of elongation at break after membrane was soaking in PBS until week-4.

\begin{tabular}{lcl}
\hline Membrane composition & Elongation at break reduction (\%) & \multicolumn{1}{c}{ Remarks } \\
\hline CTS-HA $(4 / 0 \mathrm{~g} / \mathrm{g})$ & 33.34 & Based component membrane \\
CTS-HA $(4 / 2 \mathrm{~g} / \mathrm{g})$ & 55.25 & Composite membrane \\
CTS-HA $(4 / 4 \mathrm{~g} / \mathrm{g})$ & 34.78 & Composite membrane \\
CTS-HA $(4 / 6 \mathrm{~g} / \mathrm{g})$ & 36.34 & Composite membrane \\
\hline
\end{tabular}

Table 3. FTIR spectrum identification of hydroxyapatite

\begin{tabular}{llccc}
\hline No & Functional group & \multicolumn{3}{c}{ Wave length (cm-1) } \\
\hline & & Silverstein et al. (2000) & Chen et al. (2002) & Sample \\
1 & O-H & $3200-3600$ & 3570.63 & $3205.69-3560.59$ \\
2 & P-O / P=O & $910-1040$ & $1000-1100$ & 1030.20 \\
\hline
\end{tabular}

form a crosslinked inter CTS molecule (Chen et al., 2004; Kuo, 2009). The chemical reaction on synthesis of CTS-HA membrane after soaking in $\mathrm{Na}_{2} \mathrm{SO}_{3}$ solution is forming a sulfit bridge to connect the chitosan chains (Roberts, 2002). The crosslinked structure formed is similar with the structure suggested by AlRemawi (2012), i.e. the reaction between the cation amine groups of chitosan and sulfate anions, in this case the sulfate ion is functioned as a bridge which is connecting inter-chitosan molecules.

FTIR analysis on the CTS-HA (4/2 g/g) composite membrane is conducted to know the functional group and the probability of crosslinked in its composite membrane formed. The FTIR spectrum of CTS-HA $(4 / 2 \mathrm{~g} / \mathrm{g})$ composite membrane before and after soaking in $\mathrm{Na}_{2} \mathrm{SO}_{3}$ solution were characterized by the wave lenght of certain functional group, $\mathrm{O}-\mathrm{H} ; \mathrm{C}-\mathrm{H}$ stretching; $\mathrm{C}-\mathrm{C} ; \mathrm{C}=\mathrm{O}$; and $\mathrm{P}-\mathrm{O}$, as a functional group of CTS and HA. It is presented in Table 5.

Comparing the FTIR spectrum of CTS-HA $(4 / 2 \mathrm{~g} /$ g) composite membrane before and after soaking in $\mathrm{Na}_{2} \mathrm{SO}_{3}$ solution revealed that there is a change width in spectrum of membrane after soaking in $\mathrm{Na}_{2} \mathrm{SO}_{3}$ solution. Table 5 shows that the wave lenght of specific functional groups of CTS-HA $(4 / 2 \mathrm{~g} / \mathrm{g})$ composite membrane were in the range of as stated by Silverstein et al. (2000).

After soaking the membrane in the sulfite solution, the peak width of some functional group is shorterned while some others longer. As stated previously, it is because the presence of an ionic bond to form crosslink inter CTS molecule, to form a sulfit bridge to connect the chitosan chains, (Kuo et al., 2009). Due to the steric effect with a bridge formed inter- 
Table 4. FTIR spectrum identification of CTS membrane before and after soaking in $\mathrm{Na}_{2} \mathrm{SO}_{3}$ solution .

\begin{tabular}{|c|c|c|c|c|c|}
\hline \multirow{3}{*}{ No } & \multirow{3}{*}{ Functional group } & \multicolumn{4}{|c|}{ Wave length (cm-1) } \\
\hline & & \multicolumn{2}{|c|}{ Before soaking in $\mathrm{Na} 2 \mathrm{SO} 3$ solution } & \multicolumn{2}{|c|}{ After soaking in $\mathrm{Na} 2 \mathrm{SO} 3$ solution } \\
\hline & & $\begin{array}{c}\text { Silverstein et al. } \\
(2000)\end{array}$ & Sample & $\begin{array}{l}\text { Silverstein et al. } \\
\qquad(2000)\end{array}$ & Sample \\
\hline 1 & $\mathrm{OH}$ overlap $\mathrm{NH}$ & $3000-3700$ & $3086-3600$ & $3000-3700$ & $3475.73-3650$ \\
\hline 2 & $\mathrm{CH}$ stretching & $2800-3300$ & 2873.94 dan 2883.58 & $2800-3000$ & 2885.51 dan 2983.88 \\
\hline 3 & $\mathrm{C}=0$ & $1640-1820$ & 1650 & $1600-1850$ & 1670.35 \\
\hline 4 & $\mathrm{C}-\mathrm{O}-\mathrm{C}$ & $900-1300$ & 1261.45 & $900-1300$ & 1190.6 \\
\hline
\end{tabular}

Table 5. FTIR spectrum identification of CTS-HA $(4 / 2 \mathrm{~g} / \mathrm{g})$ composite membrane before and after soaking in $\mathrm{Na}_{2} \mathrm{SO}_{3}$ solution

\begin{tabular}{|c|c|c|c|c|c|}
\hline \multirow{3}{*}{ No } & \multirow{3}{*}{ Functional group } & \multicolumn{4}{|c|}{ Wave length $(\mathrm{cm}-1)$} \\
\hline & & \multicolumn{2}{|c|}{ Before soaking in $\mathrm{Na} 2 \mathrm{SO} 3$ solution } & \multicolumn{2}{|c|}{ After soaking in $\mathrm{Na} 2 \mathrm{SO} 3$ solution } \\
\hline & & $\begin{array}{c}\text { Silverstein et al. } \\
\qquad(2000)\end{array}$ & Sample & $\begin{array}{c}\text { Silverstein et al. } \\
(2000)\end{array}$ & Sample \\
\hline 1 & OH overlap NH & $3000-3700$ & $3600-3633.89$ & $3000-3700$ & $3400.66-3620.29$ \\
\hline 2 & $\mathrm{CH}$ stretching & $2800-3000$ & 2947.23 & $2800-3300$ & 2985.81 \\
\hline 3 & $\mathrm{C}=0$ & $1600-1850$ & 1670.35 & $1640-1820$ & 1678.07 \\
\hline 4 & $\mathrm{C}-\mathrm{O}-\mathrm{C}$ & $950-1100$ & 1030.2 & $950-1040$ & 1030.2 \\
\hline
\end{tabular}

CTS molecule, some atom can move freely in an available space the others atom stay in the presence of steric hindrance.

\section{Scanning Electron Microscopy (SEM)}

The aim of Scanning electron microscope (SEM) analysis is to study the surface structure of CTS membrane and of CTS-HA composite membrane. The result is presented in Figure 5. The membrane were molded and dried in room temperature and heated in oven at $60^{\circ} \mathrm{C}$. The result showed that the surface morphology of CTS membrane is more homogen and smoother (Figure 5a) compared to the surface morphology of CTS-HA membrane (Figure $5 b$ ). It is because CTS as a raw material in CTS membrane was dissolved in $2 \%$ acetic acid solution hence its surface morphology was homogenized and smoothed. While, the HA powder is an inorganic substance, as a component of CTS-HA membrane, it was undissolved in CTS solution but it was dispersed or distributed in the CTS solution, finally it was suspended. It was shown on the cross-section morphology of CTS-HA membrane (Figure 5c), the HA powder was dispersed or distributed on the edge surface of the CTS membrane. The appearance of the surface morphology of CTS-HA membrane is roughed. On the other hand, Ramli et al. (2011) and Zo et al. (2012) prepared the CTS-HA membrane by mixing the components with continuous stirring, and molded by freeze-drying method. They obtained the components of CTS-HA membrane were distributed homogenously, the components were interacted to form a scaffold structure, and produced a porous matrix with the pores were interconnected.

\section{Conclusion}

The CTS-HA membrane can absorp water quickly, and the equilibrium condition was reached in 5 minutes.

Increased the HA content in CTS-HA membrane, the time of soaking of CTS-HA membrane in PBS, and the biodegradation rate of CTS-HA membrane, lead to decrease in the water absorption capacity, the tensile strength, and the elongation at break of membrane.

CTS took an important role in the water absorption capacity, the time of soaking, the biodegradation rate, and the tensile strength parameter of the composites. On the other hand, HA was very important at the 


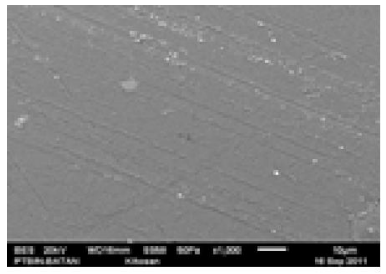

A

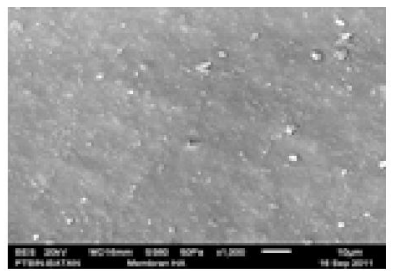

$\mathrm{B}$

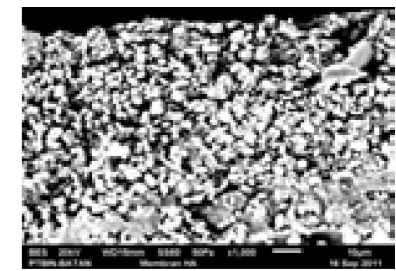

C

Figure 5. SEM photograph of CTS membrane and of CTS-HA composite membrane (1000x). (A): surface morphology of CTS membrane; (B): surface morphology of CTS-HA (2/4 g/g) composite membrane; (C): cross-section morphology of CTS-HA (2/4 g/g) composite membrane

elongation at break properties of CTS-HA membrane. Based on the result, the CTS-HA $(4 / 2 \mathrm{~g} / \mathrm{g})$ composite membrane was considered as the best formula for CTS-HA based GTR.

Result of FT-IR analysis indicated that there was a crosslinking between a CTS-HA composite membrane and $\mathrm{Na}_{2} \mathrm{SO}_{3}$ as shown in shortened width of functional group wave length.

Result of SEM analysis indicated that CTS-HA components was interacted and distributed homogenously.

\section{References}

Ai, J., Tavirani, M. R., Biazar, E., Heidari S. K., \& Jahandideh, R. (2011). Mechanical Properties of Chitosan-Starch Composite Filled Hydroxyapatite Micro- and Nanopowders. J. Nanomaterials. 1-5. Article ID 391596, 5 pages. Doi: 10.1155/2011/391596.

Al-Remawi, M. M. A. (2012). Properties of Chitosan Nanoparticles Formed Using Sulfate Anions as Crosslinking Bridges. Am. J. Appl. Sci., 9(7), 10911100.

Anonymous. (2006). Dental: Guided Tissue Regeneration Membrane. INION, Intelligent Solution. Brochures 5 pages. Accessed on 02 May 2013.

Anonymous. (2011). Global Biomaterials market worth US $\$ 58,1$ Billion by (2014). Retrieved from $h t t p: / /$ blog.taragana.com/pr/global-biomaterials-marketworth-us581-billion-by-2014-363/. Accessed on 02 May 2011.

Anonymous. (2013)a. Biomaterials Market by Products \& Applications - Global Forcasts to (2017). Dublin, April 23, (2013)/PRNewswire/-. Retrieved from: $h t t p: /$ /www.prnewswire.com/news-releases/biomatewrialsmarket-by-products-applications_-global-forcaststo-(2017)-204267531.html. Acessed on May 07, 2013.

Anonymous. (2013)b. Global Biocompatible Materials Markets to Reach US $\$ 87.7$ Billion by (2017), According to New Report by Global Industry Analysis, Inc. Retrieved from http://www.biomedtrends.com/ GetDetails.asp? CatName=Biomaterials. Accessed on May 07, 2013.
Aoki, H. (1991). Science \& medical applications of hydroxyapatite (p. 1-17). Tokyo: Takayama Press System Center.

Chen, F., Wang, Z. C., \& Lin, C. J. (2002). Preparation \& characterization of nano-sized hydroxyapatite particles \& hydroxyapatite/chitosan nano-composite for use in biomedical materials. Materials Letters, 57; 858861.

Chen, T. W., Kuo, S. M., Chang, S. J., \& Kuan, T. C. (2004). Fabrication \& Evaluation of Chitosan Membranes for Guided Tissue Regeneration. Biomed. Eng. Appl. Basis Comm, 16, 259-264.

Freitas, R. M., Spin-Neto, R., Spolidorio, L. C., CampanaFilho, S. P., Marcanton io, R. A. C., \& Marcantonio, E. Jr., (2011). Different Molecular Weight Chitosan-Based Membrane for Tissue Regfeneration. Materials, 4; 380389. Doi: $10.3390 / \mathrm{ma} 4020380$.

Kuo, S. M., Niu, G. C. C., Lan, C. W., Cheng, M. F., Chiang, M. Y., \& Chang, S. J. (2009). Guided Tissue Regeneration with Use of $\mathrm{CaSO}_{4}$-Chitosan Composite Membrane. J. Med. \& Biol. Eng., 29(6), 304-310.

Kuo, S. M., Chang, S. J., Niu, G. C. C., Lan, C. W., Cheng, W. T., \& Yang, C. Z. (2009)a. Guided Tissue Regeneration with Use of â-TCP/Chitosan Composite Membrane. J. Appl. Polym. Sci., 112, 3127-3134.

Peniche, C., Solis, Y., Davidenko, N., \& Garcia, R. (2010). Chitosan/hydroxyapatite-based composites. Biotecnol. Apl. 27(3): 1-18. Retrieved from http:// scielo.s/d.cu/scielo. php?script=sciarttext\&pid=S102728522010000300002 May 07, 2013.

Ramli, R. A., Adnan, R., Bakar, M. A., \& Marsudi, S. M. (2011). Synthesis and Characterization of Pure Nanoporous Hydroxyapatite. J. Phys. Sci., 22(1), 25-37.

Roberts, G. A. F. (2002). Chitosan condensation products, thewir preparation and their uses. US Patent EP 1250359 A1.

Silverstein, M., Webster, F. X., \& Kiemle, D. J. (2000). Spectrometric identification of organik compounds ( $p$. 72-80, 215-217). 7th ed. New York: John Wiley and Sons.

Tal, H., Moses, O., Kozlovsky, A., \& Nemcovsky, C. (2012). Bioresorbable Collagen Membranes for Guided Bone Regeneration. In: Tal, H. (Ed.). Bone 
Regeneration. ISBN: 978-953-51-0487-2. In Tech. Retrieved from http://www.intechopen.com/books/ bone-regeneration/bioresorbable-collagenmembranes-for-guided-bone-regeneration. Accessed on May 03, 2013.

Teng, S. H., Lee, E. J., Yoon, B. H., Shin, D. S., Kim, H. E. \& Oh, J. S. (2008). Chitosan/nanohydroxyapatite composite membranes via dynamic filtration for guided bone regeneration. J. Biomed. Mater. Res., Part A. 84, 569-580.
Wawro, D. \& Pighinelli, L. (2011). Chitosan Fibers Modified with Hap/â-TCP Nanoparticles. Int. J. Mol. Sci., 12, 7286-7300. Doi: 10.3390/ijms12117286.

Yuan, N. Y., Tsai, R. Y., Ho, M. H., Wang, D. M., Lai, J. Y., \& Hsieh, H. J. (2008). Fabrication and characterization of chondroitin sulfate-modified chitosan membranes for biomedical applications. Desalination, 234, 166174.

Zo, S. M., Singh, D., Kumar, A., Cho, Y. W., Oh, T. H., \& Han, S. S. 2012. Chitosan-hydroxyapatite macroporous matrix for bone tissue engineering. Current Science, 103 (12), 1438-1446. 